\title{
56. DATA REPORT: UNDERWAY GEOPHYSICS: REGIONAL CHARACTERISTICS OF SEISMIC-REFLECTION DATA FOR LEG $135^{1}$
}

\author{
Lindsay M. Parson ${ }^{2}$
}

\section{INTRODUCTION}

Underway geophysical data, and particularly seismic-reflection profiles, are an important part of the Ocean Drilling Program (ODP) because not only do they help define the scientific problems to be addressed by drilling, but they also ensure the selection of optimum sites and enable the necessary safety criteria to be satisfactorily addressed. This chapter describes the acquisition and display of the seismicreflection data collected on board JOIDES Resolution during Leg 135 and includes a discussion of the regional structure and stratigraphic content identified from the seismic-reflection data.

\section{SHIPBOARD UNDERWAY GEOPHYSICS}

During Leg 135, JOIDES Resolution was equipped to acquire, display, and process a variety of geophysical data, including underway navigation, bathymetric, magnetic, and single-channel seismicreflection data. Digital logging of most of these data facilitates postcruise processing. Navigational, bathymetric, and magnetics data are routinely edited and corrected by the Geological Data Center (GDC) at Scripps Institution of Oceanography under contract to ODP. Merged digital data are produced in MGD77 Exchange Format and, along with microfilm copies of all original analog records, are available from the Data Librarian at ODP headquarters, College Station, Texas; the Site Survey Data Bank at Lamont-Doherty Geological Observatory, Palisades, New York; and the National Geophysical Data Center, Boulder, Colorado.

The equipment and methods used for the acquisition of underway geophysical data aboard JOIDES Resolution are briefly described below. This is then followed by a description and discussion of the seismic-reflection data collected at each site during Leg 135.

\section{Navigation}

\section{Equipment and Methods}

Primary navigation data were acquired during Leg 135 by a Magnavox Model MX 1107 Transit/Global Positioning System (GPS) satellite navigator, located in the underway geophysics laboratory. The GPS was available for up to $20 \mathrm{hr}$ each day. In addition, transit satellite fixes were obtained throughout the day to enable the calculation of dead-reckoning positions. All fixes, together with course and speed information, were digitally recorded in a computer file at selected time intervals (typically every $2 \mathrm{~min}$ while acquiring seismic data) using a Masscomp super-microcomputer system. These data were used to produce plots of the ship's position as a function of time. Fixes collected while on site were averaged to produce its precise

\footnotetext{
${ }^{1}$ Hawkins, J., Parson, L., Allan, J., et al., 1994. Proc. ODP, Sci. Results, 135: College Station, TX (Ocean Drilling Program).

${ }^{2}$ Institute of Oceanographic Sciences Deacon Laboratory, Brook Road, Wormley, Godalming GU8 5UB, United Kingdom.
}

location. Navigation data were compiled in real time and used for track-line displays.

\section{Transits Between Sites}

Underway geophysical data were collected on Leg 135 during transits to and between drill sites. The data collected include (1) 3.5 and $12-\mathrm{kHz}$ precision echo-sounder profiles, (2) total intensity measurements of the Earth's magnetic field, (3) single-channel seismicreflection profiles (collected in the vicinity of, and over, each site), and (4) underway navigation data.

\section{Bathymetry}

\section{Equipment and Methods}

Bathymetric data were acquired using both the $3.5-$ and $12-\mathrm{kHz}$ profiling systems and displayed using Raytheon Model 1807M LSR linescan recorders, which were operated generally at a 1-s sweep rate. Transducers for both systems are mounted in a sonar dome installed to improve noise conditions at high ship speeds and in rough weather conditions. The $3.5-\mathrm{kHz}$ system provided some information regarding sub-bottom acoustic stratigraphy, generally with penetration of tens of meters, dependent on sediment type.

\section{Magnetics}

\section{Equipment and Methods}

Measurements of the total intensity of the Earth's magnetic field were collected along the ship's track by a Geometrics 801 protonprecession magnetometer. The sensor was towed approximately 400 $\mathrm{m}$ behind the ship. Measurements were made at 3 -s intervals with a sensitivity of about $1 \mathrm{nT}$. Values were digitally recorded in the header of the seismic-reflection data on the Masscomp computer every $99 \mathrm{~s}$ during nonseismic transit periods and once per shot (12-s interval) while acquiring seismic-reflection data. The magnetics data were also displayed in analog form on a strip-chart recorder in real time, with manual entries of the magnetic field intensity logged every $5 \mathrm{~min}$. The magnetics data were processed later by the GDC to remove the regional International Geomagnetic Reference Field and to correct time variations.

\section{Seismic-Reflection Profiling}

\section{Equipment and Methods}

The seismic-reflection data collected across drilling sites during Leg 135 are described in the following site sections. The ship's tracks along which seismic-reflection data were collected are shown in Figures $1 \mathrm{~A}-1 \mathrm{H}$. To conduct the pre-site survey the ship slowed to 6 knots to deploy the underway geophysical equipment.

\section{Seismic Source}

The seismic source used for underway reflection profiling during Leg 135 consisted of two 80 -in. ${ }^{3}$ water guns fired at approximately 

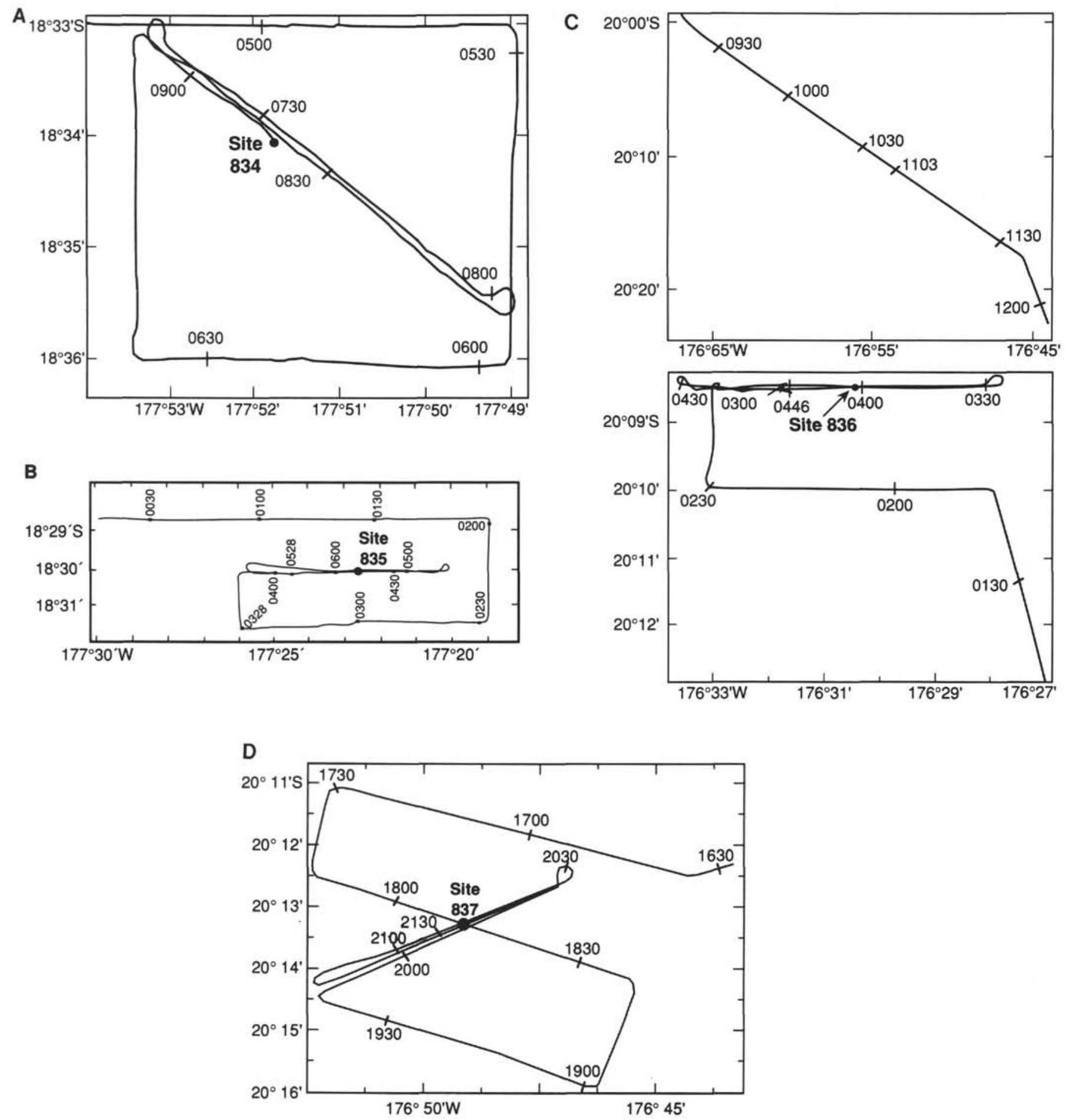

Figure 1. Track charts of JOIDES Resolution underway geophysics lines collected during Leg 135 for Sites 834 through 841 (A-H). These refer to and locate seismic-reflection profiles illustrated in Figures 2-9. 

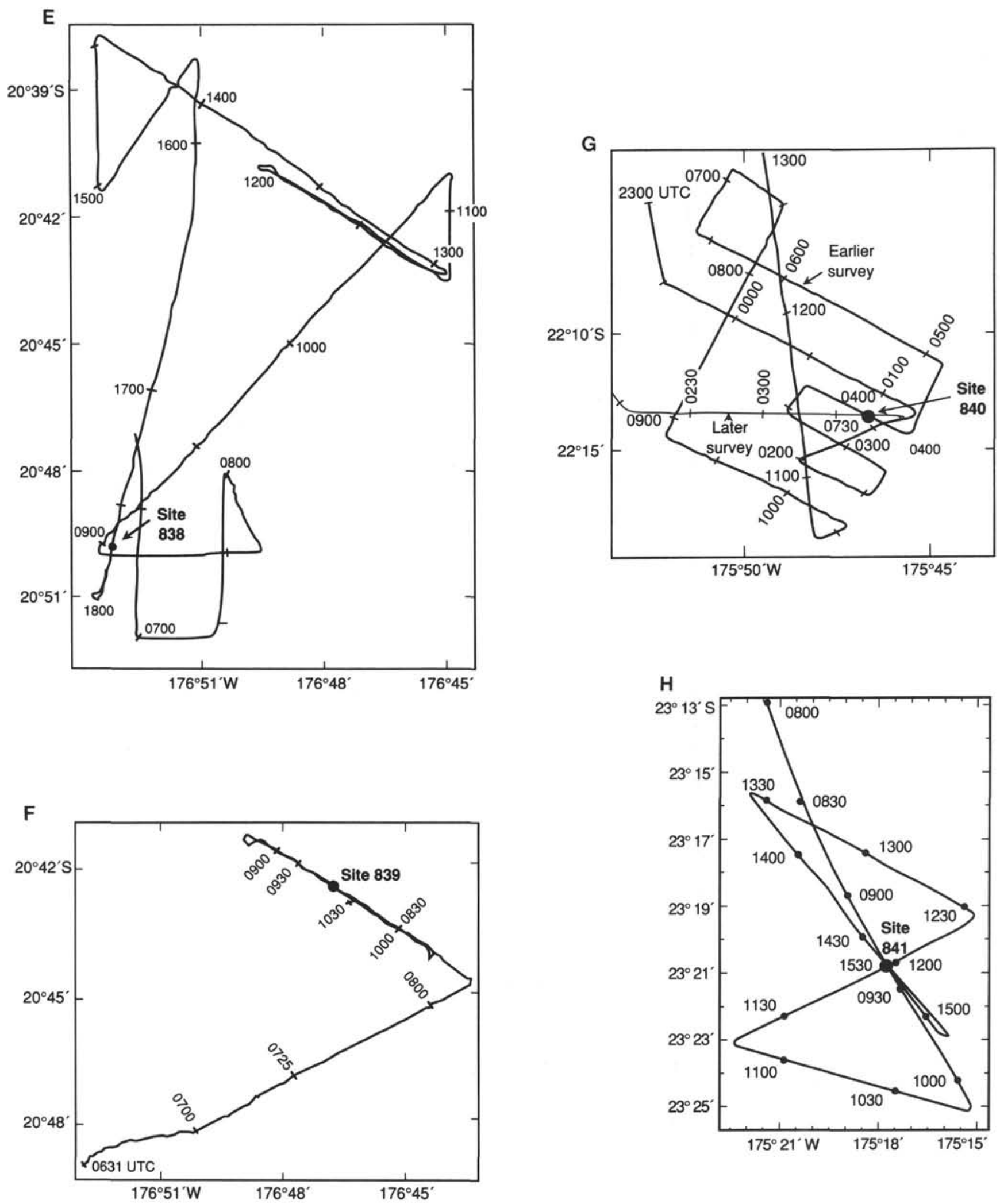

Figure 1 (continued). 
$2000-\mathrm{lb}$ pressure. The guns were towed approximately $14 \mathrm{~m}$ apart roughly $25 \mathrm{~m}$ behind the ship. The gun firing rate was every $12 \mathrm{~s}$.

\section{Hydrophone Streamer}

One 100-m Teledyne hydrophone streamer was towed from the fantail during the Leg 135 seismic-reflection profiling program. The streamer was towed approximately $500 \mathrm{~m}$ behind the vessel. The output signals of the 60 active hydrophone elements of the streamer were summed to produce a single seismic signal.

\section{Seismic Data Recording}

Real-time analog, seismic-reflection data were displayed on two Raytheon linescan recorders. The seismic signal from the hydrophone streamer was amplified and bandpass-filtered at a variety of frequency settings to optimize reflector resolution before display.

The seismic reflection data were also simultaneously recorded in digital format by the Masscomp super microcomputer. Data were filtered and displayed in real time on a 15-in. Printronix high-resolution graphics printer (resolution of 160 dots per inch). Filtered seismic data were recorded in SEG Y format at a density of 1600 bits per inch. During times when seismic-reflection profiles were not being recorded, there was opportunity to replay seismic data and compare results of different filter settings.

\section{BACKARC SITES}

Sites 834 through 839 were located with the intention of obtaining a time sequence of backarc samples from the oldest (westernmost) portion of the Lau Basin to the youngest (easternmost) crust. As discussed elsewhere in this volume, the recovered lithologies and their ages proved that the geological evolution of the basin is more complex than previously suggested (Karig, 1970; Hawkins, 1974; Parson et al., 1990).

\section{Site 834}

The physiographic setting of Site 834 is at the westernmost margin of the central Lau Basin in a moderately steep-sided trough, which trends roughly north-south and lies parallel to the eastern flank of the adjacent Lau Ridge. Single-channel seismic-reflection profiles collected by the Charles Darwin and the Thomas Washington in 1988 and 1989, respectively (Parson et al., 1989; Hawkins, 1989), were used to identify a suitable seismostratigraphic section for investigation during Leg 135 drilling. A short pre-site survey was undertaken using JOIDES Resolution to target the exact site.

The underway geophysical equipment was deployed between 0445 and 0710 UTC (Universal Time Coordinated), 21 December 1991. A box survey was then run around the proposed site, with track lengths of approximately $6 \mathrm{~km}$. Two final northwest-southeast diagonal tracks were occupied between 0715 and 0835 UTC, at which point the beacon was dropped to mark the site (Fig. 1A).

A preliminary interpretation of the seismic sections crossing Site 834 has been presented in the Initial Reports volume of the Leg 135 Proceedings. In detail, a regional acoustic basement reflector can be identified throughout the seismic profile illustrated in Figures $2 \mathrm{~A}$ and 2B. It occurs between 0.15 and $0.2 \mathrm{~s}$ two-way traveltime (TWT) below seafloor and forms a high-amplitude, locally mounded and irregular surface, occasionally sharply truncated by steep surfaces interpreted as fault offsets. It is locally flat-lying and subparallel with the overlying sediment and forms an apparently conformable blanket sequence. Displacements of more than $0.4 \mathrm{~s}$ TWT-approximately $400 \mathrm{~m}$-locally offset the basement surface and result in the irregular character of the acoustic basement reflector. The ubiquitous sediment cover extends for at least $0.15 \mathrm{~s}$ TWT as a laminated seismic sequence interpreted as a predominantly pelagite-rich sediment drape. With-

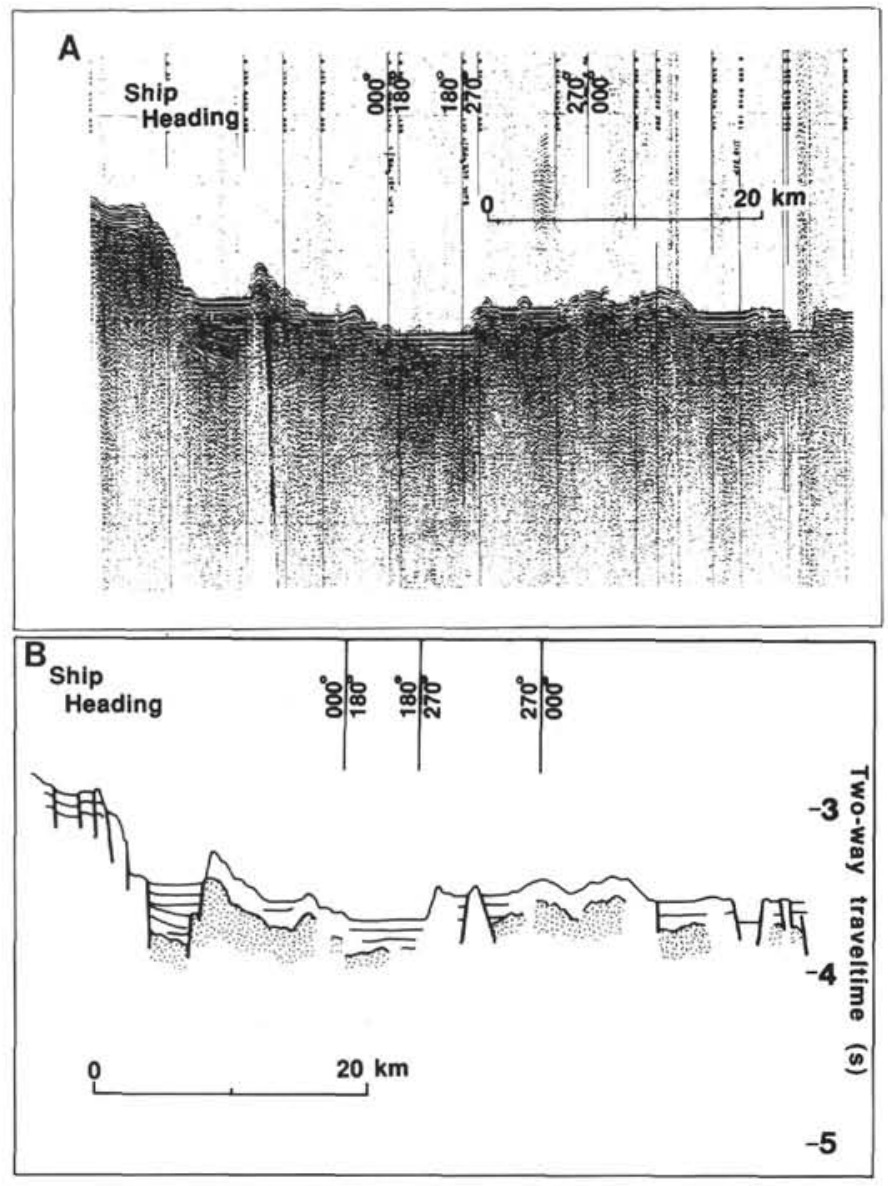

Figure 2. A. Seismic-reflection profiles acquired during Site 834 survey and approach. B. Line-drawn interpretation of Figure 2A. Stipple marks = "acoustic basement." Steep bold lines are faults.

in several of the basins, however, the acoustic basement exhibits a marked angular unconformity with a horizontal onlapping sediment sequence. Another sub-basin, lying immediately at the foot of the Lau Ridge, to the west of Basin 834, was avoided during Leg 135 drilling because of the possibility of encountering excessive amounts of material mass-wasted from the Lau island group. In this basin a lower sediment sequence 0.1 to $0.15 \mathrm{~s}$ TWT thick conformably overlies the easterly dipping acoustic basement surface, which appears to be bounded to the east and the west by normal faults. Above this lower sedimentary unit, a sequence of flat-lying, planar-laminated seismic units (up to $0.2 \mathrm{~s}$ TWT thick) onlap to the west, in the eastern part of the basin. Total resolved thickness is more than $0.35 \mathrm{~s}$ TWT.

Apart from the major faults controlling the gross basement configuration-and presumably to a large degree the first-order sedimentation processes-steeply inclined minor faults cut and locally outcrop in the uppermost sedimentary section. The majority of the structures are normal faults, although several dislocations of the section display no offset and are speculated to be strike-slip structures. Immediately adjacent to the east of Site 834, a steep-sided, and apparently faultbounded, trough downthrows the basin floor by some $0.12 \mathrm{~s}$ TWT without disturbing the section. Data collected during other cruises confirm the trough to be a gently sinuous channel extending for at least $30 \mathrm{~km}$ in a north-south orientation.

\section{Site 835}

The physiographic setting of Site 835 is described elsewhere (Parson, Hawkins, Allan, et al., 1992), and is only briefly summarized here. The general outline of the basin is of a north-south "boat" shape, 
tapering to the south and open to the north, with a maximum width of $7.5 \mathrm{~km}$ and at least $65 \mathrm{~km}$ in length. The basin, referred to as Basin 835 , was crossed before the JOIDES Resolution survey program by a number of intersecting single-channel seismic-reflection profiles acquired by the Charles Darwin and Thomas Washington during 1988 and 1989, respectively (see Hawkins, 1989; Parson et al., 1990; Parson et al., this volume).

To conduct the pre-site survey, the ship slowed at 0018 UTC on 31 December 1991 to deploy the underway geophysical equipment described herein. The site survey was completed by 0514 UTC, and included a series of four east-west tracks and linking north-south tie lines. Two east-west profiles were each collected $1.5 \mathrm{nmi}$ to the north and south of Site 835 to provide some detail on along-strike structural variations (Fig. 1B).

Some preliminary interpretations have been presented of the track crossing the site in the Initial Reports volume (Parson, Hawkins, Allan, et al., 1992). Included here are all additional profiles collected during Leg 135 along with interpretations (Figs. 3A and 3B).

The seismic-reflection data collected by JOIDES Resolution in the vicinity of Site 835 shows a series of ridges ranging from $1000 \mathrm{~m}$ to less than $200 \mathrm{~m}$ in elevation above an intervening series of flatlying, sediment-filled basins. A clear acoustic basement surface occurs throughout much of the profile, very similar to the strong, highamplitude, semicontinuous, gently undulating event underlying much of the Basin 834 section. Acoustic basement is difficult to resolve, however, within the ridges. They are rarely pinnacled and present a generally smooth-surfaced subdued crustal topography, suggesting a significant sediment cover. Exact delineation between the sediment drape and the basement core within the ridges is rarely possible and has not been attempted on these interpretations (Fig. 3B). Sediment sections filling the sub-basins consist of predominantly flat-lying, parallel, uniform horizons, although the seismic section at the foot of the easterly flank of Basin 835 reveals at least one narrow, wedge-shaped unit interpreted as a slump/debris flow deposit (Parson, Hawkins, Allan, et al., 1992). The section corresponding to the debris flow unit is almost completely obscured by the gun signal.

The upper surface of Basin 835 in the vicinity of Site 835 dips gently to the east, but to the south of the site, the margins of the basin floor shoal slightly to form a saucer-like profile (Fig. 3). To the north of Site 835, acoustic basement is overlain by a thin conformable sequence about $0.05 \mathrm{~s}$ TWT thick, and both surfaces have an eastward apparent dip of more than $2^{\circ}$. Overlying this, an angular unconformity has developed as westerly onlapping horizontal beds that fill the half-graben. Structural similarities are present in the morphology, scale and internal configuration of this basin and that described previously for the sub-basin to the east of Basin 834 .

\section{Site 836}

The physiographic and morphotectonic setting of Site 836 is described elsewhere (Parson, Hawkins, Allan, et al., 1992) and is only briefly summarized here. Basin 836 is approximately $20 \mathrm{~km}$ long in a north-northeast direction and about $5 \mathrm{~km}$ wide, forming a narrow and irregular oval shape. A number of short, single-channel seismicreflection profiles collected by the Charles Darwin and Thomas Washington during 1988 and 1989, respectively (Parson et al., 1990; Hawkins, 1989), provided the background data for the location of Site 836 and the positioning of the JOIDES Resolution site survey.

Two portions of seismic-reflection data were collected during Leg 135 pre-site surveying of Site 836 . They comprise (1) a single northwest-southeast line acquired between 0930 and 1200 UTC on 4 January 1992 en route to the prospective Site 840 and (2), a series of east-west traverses between 0145 and 0358 UTC on 6 January (Fig. 1C). These data are presented in Figures $4 \mathrm{~A}$ and $4 \mathrm{C}$, along with line interpretations (Figs. 4B and 4D). It was recognized on board that there were great difficulties in identifying the exact thickness of sediment from the single-channel seismic data, although some minimum estimates were possible from the $3.5-\mathrm{kHz}$ profiles. The significant sediment cover can be resolved as a package of flat-lying, subparallel seismic reflectors on these data at the margins of Basin 836, although in the central portion of the basin, the seafloor is a highly reflective, acoustically opaque surface, probably representing scoured and largely unsedimented basement.

The acoustic signature of both of the profiles collected across Site 836 is one of a surface or near-surface, high-amplitude reflector, which forms an irregular, locally pinnacled or ridgelike terrain. Between the ridges, which rise locally to $400 \mathrm{~m}$ above the surrounding seafloor, narrow sub-basins or troughs with gently undulating or planar floors are common. It is difficult to present an unambiguous interpretation of the seismic-reflection signature in these zones owing to interference from the gun signal, but overall the section is dominated by flat-lying surfaces and any sub-bottoms, should they exist, are obscured. Our provisional interpretation of these data was that some limited sediment ponding could occur in these areas and probably forms a predominantly volcaniclastic-rich, seismically opaque unit. It is acknowledged, however, that an alternative interpretation could be that they are the bare surfaces of sheet flow extrusives (Parson, Hawkins, Allan, et al., 1992). The 3.5- and 12-kHz profiler data across Basin 836 clearly reveal some indications of sub-bottoms at the flanks of the basins. Drilling results from Site 836 have subsequently proved that minimal sediment cover exists in the axis of the basin.

\section{Site 837}

A summary of the physiographic and morphotectonic setting of Site 837 is presented in Parson, Hawkins, Allan, et al. (1992) and is only briefly summarized here. Basin 837 is approximately $10 \mathrm{~km}$ long at its northeast-southwest axis, has a narrow linear form, and contains a well-developed seismic sequence comprising flat-lying, planarparallel reflectors.

The underway geophysical survey equipment was deployed at 1526 UTC on 8 January 1992. As discussed in the Leg 135 Initial Reports volume, a series of three profiles were acquired in an approximately west-northwest orientation to traverse the basin and crossed with two further east-northeast profiles to provide a three-dimensional framework for the site. All the profiling was completed by 2050 UTC on 8 January, at which point a beacon was dropped to mark the site (Fig. 1D).

A selection of the seismic-reflection profiler data recorded was presented in the Initial Reports volume of Leg 135. Presented here are all of the seismic data in the vicinity of Site 837 (Fig. 5A) and their interpretation (Fig. 5B).

The seismic profile acquired by JOIDES Resolution across Basin 837 exhibits a series of alternating hummocky ridges separated by narrow sub-basins filled with regularly laminated and horizontal seismic strata. A high-amplitude, low-frequency reflector can be traced as a gently mounded surface at up to a depth of $0.16 \mathrm{~s}$ TWT below the seafloor reflector in each of the sub-basins. We interpret this to be the equivalent of acoustic basement recognized elsewhere at previous sites. Within the ridges, the differentiation between the acoustic basement surface and the overlying sediment cover is difficult because of the chaotic pattern of reflectors and diffraction hyperbolae therein. Locally, however, small but distinct, flat-lying reflector packages occur in minor troughs on the upper surface of the ridges and are tentatively interpreted as trapped sediment ponds.

The steep sides to the sediment section in Basin 837 are locally fault-bounded (Fig. 5A). Offsets of reflectors on the eastern flank of the central portion of Basin 837 and the adjacent weak divergence of horizons suggest some local syntectonic sedimentation. In addition, the westerly inclined floor in the adjacent basin to the east of Basin 837 could be interpreted as resulting from the rapid accumulation of mass-wasted deposits. Faulting, apart from that bounding the basins, appears to be negligible. 

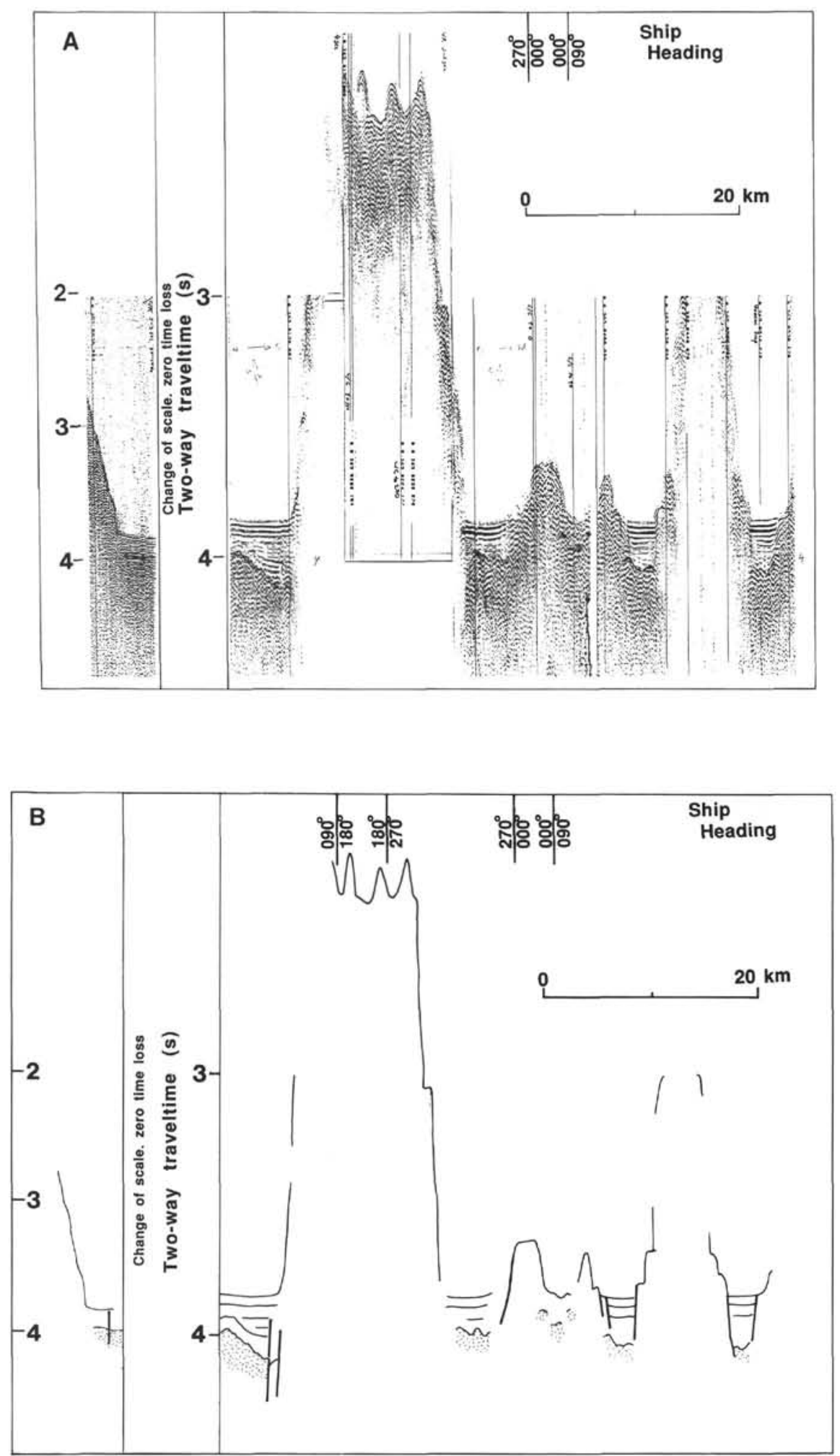

Figure 3. A. Seismic-reflection profiles acquired during Site 835 survey and approach. B. Line-drawn interpretation of Figure 3A. Stipple marks = "acoustic basement." Steep bold lines are faults. 
A

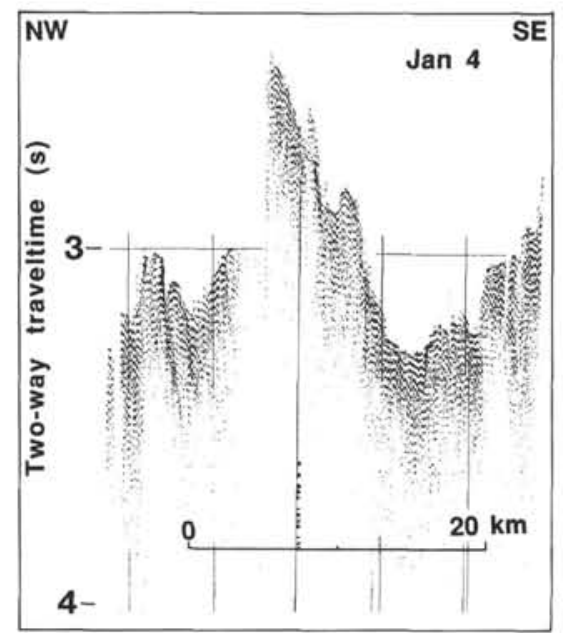

B

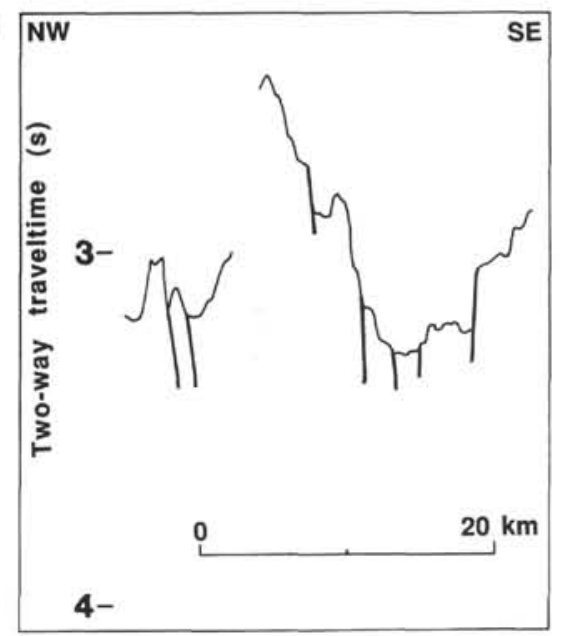

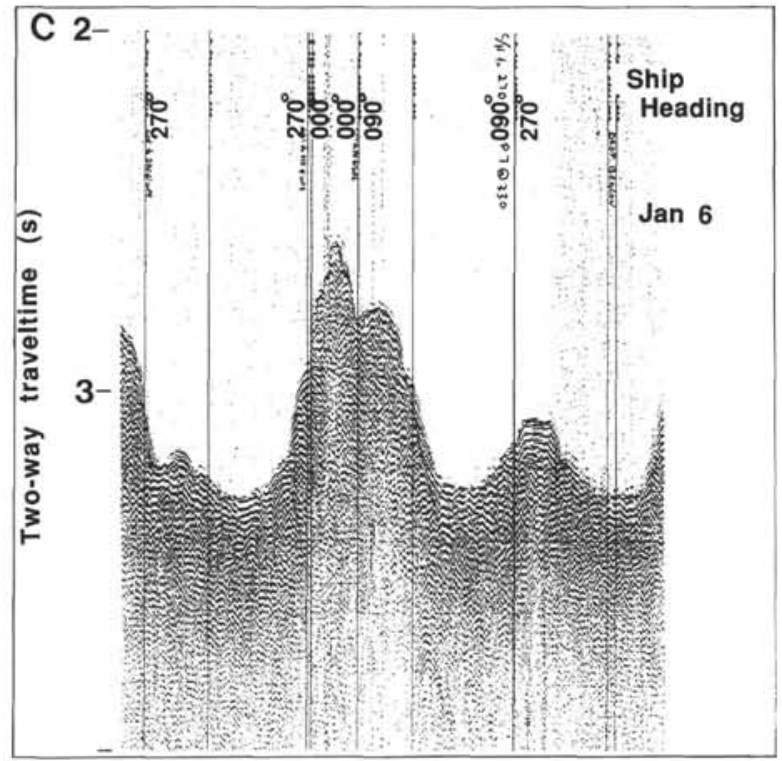

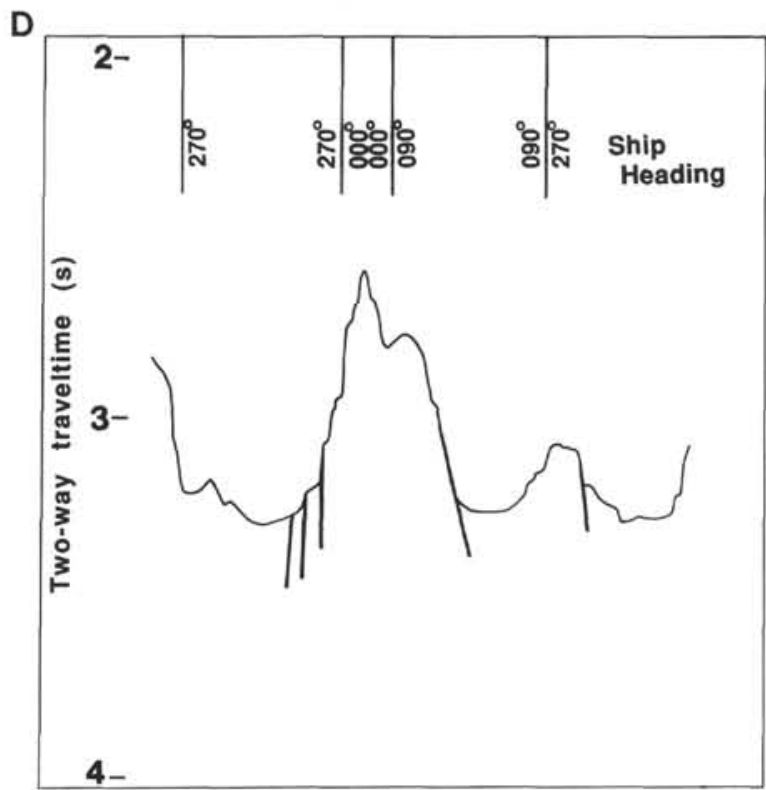

Figure 4. A. Seismic-reflection profiles acquired during Site 836 survey. B. Line-drawn interpretation of Figure 4A. Steep bold lines are faults. C. Seismic-reflection profiles acquired during Site 836 approach lines. D. Line-drawn interpretation of Figure 4C.

\section{Site 838}

A general survey of the physiographic and morphotectonic setting of Site 838 is presented in Parson, Hawkins, Allan, et al. (1992) and is only briefly summarized here. Site 838 is located on the southwest flank of Basin 838, a narrow, sedimented, linear trough with an approximately boat-shaped form that tapers to the north.

Intersecting single-channel seismic-reflection profiles recorded by the Charles Darwin and the Thomas Washington in 1988 and 1989 , respectively, were used to assess the regional morphology of the site (Parson and Rothwell, this volume; Parson, et al. 1990; Hawkins, 1989). A number of pre-site survey seismic lines were acquired to provide an accurate seismostratigraphic context for the drilling.

The underway geophysical equipment was deployed at 0615 UTC on 11 January 1992. An 18-nmi geophysical survey around Site 838 commenced at 0635 UTC and was completed by 0939 UTC (Figs. $1 \mathrm{E}, 6 \mathrm{~A}$, and $6 \mathrm{~B})$. Further lines were added to this survey to the north and northeast to provide background data for prospective Site 839 . This additional survey was completed by 1600 UTC, 11 January, and JOIDES Resolution returned to Site 838 to drop the marker beacon at 1814 UTC (Fig. 1E).

The seismic data acquired during the site survey is illustrated in Figures $6 \mathrm{~A}$ and $6 \mathrm{C}$, along with line-drawing interpretations in Figure 6B.

Site 838 lies on the northwestern flank of an irregularly shaped trough referred to here as Basin 838 . In general, the topography is extremely irregular, comprising rounded ridges and basins with slightly undulating surfaces. It is difficult to identify a continuous seismic event equivalent to acoustic basement identified in the preceding discussion. This may be a result of the area being intersected by a large number of closely spaced normal dip-slip fault structures that have disrupted the section.

The upper section of the sub-basin fill is predominantly a planar laminated sequence of seismic reflectors, which extends to a maximum thickness of well over $0.2 \mathrm{~s}$ TWT. Below this unit, seismic 
A

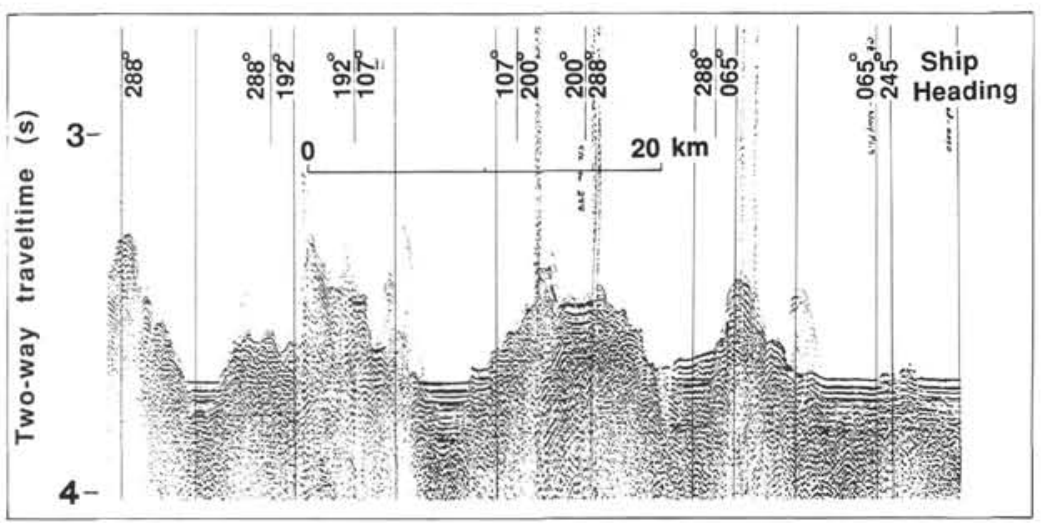

B

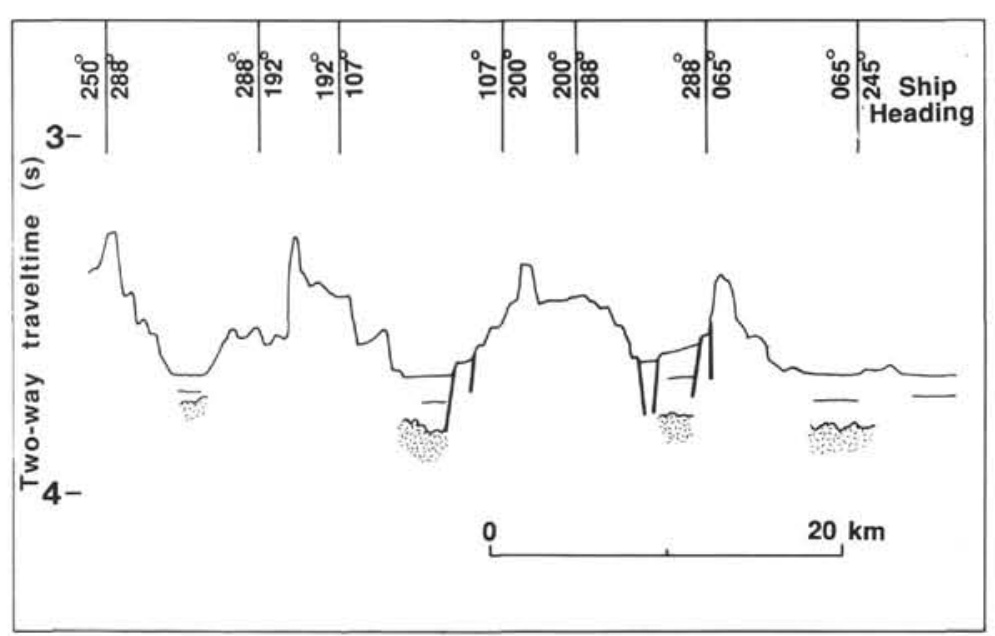

Figure 5. A. Seismic-reflection profiles acquired during Site 837 survey and approach. B. Linedrawn interpretation of Figure 5A. Stipple marks = "acoustic basement." Steep bold lines are faults.

resolution is poor probably due to faulting, and hence it is almost impossible to resolve the true thickness of the sequence. Normal faulting is pervasive throughout the section dropping the basin floor to the south. Where acoustic basement can be resolved (Fig. 6A), closely spaced dip-slip structures displace the surface down more than $0.8 \mathrm{~s}$ TWT beneath the basin axis and penetrate the upper section. These structures outcrop locally at the surface, producing an irregular terraced form to the basin margins. Adjacent fault-bounded sections of the upper sedimentary sequence may show an opposite sense of dip, suggesting some rotation during deformation. Moderate to shallowly inclined upper surfaces to the section dip up to $2^{\circ}$ without any significant slumping/mass-wasting deformation. One interpretation is that the block rotation is relatively recent, bounded in the south by a subvertical actively slipping fault. Elsewhere, other portions of the section are characterized by packages of inclined reflectors. In summary, this profile appears to record a long period of repeated and persistent deformation.

\section{Site 839}

The regional physiography and morphotectonics of Basin 839 at Site 839 has been presented in Parson, Hawkins, Allan, et al. (1992) and is only briefly summarized here. Site 839 is located in a deeply sedimented north-trending basin, approximately $5 \mathrm{~km}$ wide and at least $15 \mathrm{~km}$ long. We now recognize that this site is located upon the easternmost portion of the attenuated and rifted arc crust that forms the western part of the Lau Basin.
A set of exploratory geophysical lines was completed by JOIDES Resolution before the final site survey operation at Site 838 (Figs. 1E, $6 \mathrm{~A}$, and $6 \mathrm{~B}$ ), which were followed by two approach lines run immediately before the beacon drop (Figs. 1F, 7A, and 7B). The earlier survey lines consist principally of three northwest-southeast transit lines, each approximately $5 \mathrm{nmi}$ in length. These lines were occupied between 1110 and 1345 UTC, 11 January 1992. For the pre-site approach lines, the underway geophysical equipment was deployed at 0800 UTC. The marker beacon for Site 839 was dropped at 0945 UTC and the underway geophysical gear was recovered immediately afterward (Fig. 1F).

The regional morphology at Site 839 consists of a series of elevated horst blocks separating deeply sedimented basins, with predominantly flat-lying or gently inclined surfaces. The acoustic basement surface occurs at depths of up to $0.31 \mathrm{~s}$ TWT below the seafloor in the halfgrabens, where it forms a steeply inclined, generally smooth surface, dipping commonly into a southeasterly facing normal fault (Fig. 7A). Elsewhere, the basement surface is less readily recognizable, particularly within the horst and ridge elevations, where a confused pattern of primary reflectors and diffraction hyperbolae exist.

Seismic sections within the grabens and half-grabens at Site 839 exhibit highly distinctive geometries. The acoustic basement surface is resolved as a rotated surface flooring the southeasterly facing half-graben. Where present on these sections, a broadly conformable semi transparent unit up to a maximum thickness of $0.12 \mathrm{~s}$ TWT immediately overlies the acoustic basement, and is itself overlain by a regular sequence of planar laminated flat-lying units. This regularly 
laminated sequence onlaps the lowermost unconformable sequence. The uppermost unit comprises a section less than $0.07 \mathrm{~s}$ TWT thick and is represented by a uniform sediment drape of the basin.

The major controlling fault of the half-graben is clearly traceable along the northwest flank of Basin 839. In detail, a series of narrow ledges on the horst flank indicate that the fault is a composite structure comprising at least three parallel components. Some minor faults have been interpreted to offset the acoustic basement in the floor of Basin 839 and local subordinate structures displace seismic reflectors in the mid-section of the basin fill.

Sites 834 through 839 of Leg 135 completed the surveying and drilling program addressing the backarc objectives outlined in Parson, Hawkins, Allan, et al. (1992). The last two sites, 840 and 841, were designed to sample sections on the Tonga Ridge and Tonga forearc, respectively.

\section{ARC AND FOREARC SITES}

\section{Site 840}

Site 840 is the shallowest of the Leg 135 sites, occupying a position close to the topographic axis of the southern Tonga Ridge, part of the proto-arc originally comprising the Lau and Tonga ridges as well as the Fiji Island group platform. During Leg 135, an extensive seismic site survey was completed in the vicinity of Site 840 as a requirement of the ODP Pollution Prevention and Safety Panel (PPSP). Published discussions of reported active oil seeps at the Tongan Island group (Sandstrom, 1985; Buchbinder and Halley, 1985) had alerted the PPSP to the possibility of potential hydrocarbon accumulations in structural or stratigraphic traps in the vicinity of prospective Site 840 . It was therefore necessary to acquire closely spaced seismicreflection data to ensure that the drilling was positioned to avoid any such potential hazard. This grid of seismic lines is illustrated in Figure $1 \mathrm{G}$ and the data acquired and line-drawing interpretations are in Figures $8 \mathrm{~A}$ and $8 \mathrm{~B}$. In addition, immediately pre-site seismic lines were occupied as illustrated in Figures 8C and 8D.

The overall morphology of the upper surface is a relatively smooth and locally flat-lying platform, interrupted by numerous shallow steps and offsets of up to $200 \mathrm{~m}$, but most of which are less than $50 \mathrm{~m}$. Some distinct sections of mounded or undulatory topography could be either slump structures or weak compressional-strain effects. These features are rare, however. The section is dominated throughout by welldefined seismic laminae that are readily resolved to depths of $>1.0 \mathrm{~s}$ TWT. The majority of the reflectors are parallel or subparallel, but there are numerous examples of low-angle unconformities interrupting the section. Normal faulting is pervasive throughout the entire section. Fault structures outcrop at the platform surface and locally penetrate the entire section. Other faults were observed only as internal offsets, which can be mapped through less than $0.05 \mathrm{~s}$ TWT of the section, bounded both above and below by unbroken reflectors.

\section{Site 841}

The physiographic and morphotectonic setting of Site 841 is described elsewhere (Parson, Hawkins, Allan, et al., 1992) and is only briefly summarized here. The site is located on the flank of a small elongate domal feature on the inner (Tonga) trench wall. Multichannel-seismic lines acquired by the U.S. Geological Service in 1982 (Mann, 1985; Herzen and Exon, 1985) were combined with singlechannel profiles collected by Parson et al. (1989) to assess the regional setting of Site 841 . Additional data were collected by JOIDES Resolution during Leg 135 to identify a location where all the objectives of the site could be addressed.

The underway geophysical data was deployed at 0630 UTC, 30 January 1992. The site survey program was undertaken between 0710 and 1443 UTC, at which point the beacon was dropped to mark the site (Fig. 1H).
Seismic reflection profiler records acquired by JOIDES Resolution across Site 841 are presented in Figure $9 \mathrm{~A}$ and a line-drawn interpretation is presented in Figure 9B. The site survey took longer than anticipated mainly as a result of the need to establish a site where an acoustic basement surface could be easily resolved.

The irregular basement surface was a predominantly gently undulating surface, defined by a semicontinuous, high-amplitude, lowfrequency reflector (Fig. 9A). This surface is locally truncated and offset, although fault structures are not readily resolved in the deeper parts of the section. This basement reflector lies at a depth between 0.4 and $0.5 \mathrm{~s}$ TWT below the seafloor throughout the section and is overlain by a uniformly thick, seismically semiopaque unit displaying local seismic. In some parts of the upper section, the shallowest $0.1 \mathrm{~s}$ TWT exhibits well-developed seismic layering (for example, between 0710 and 1000 UTC, 30 January). Despite its opacity, however, this upper section was provisionally interpreted as a sediment sequence prior to drilling and was subsequently confirmed as such during Leg 135 .

Faults cut both the basement surface and the overlying sediment. On cross-strike seismic lines, steep slopes such as the inner trench are cut by multiple, parallel, normal dip-slip structures stepping down with offsets usually less than $200 \mathrm{~m}$. Elsewhere on less steeply dipping surfaces, crumpling and buckling of the uppermost sediments into an undulating asymmetric mounded form suggests slumping and gravity-sliding processes in operation.

\section{REFERENCES}

Buchbinder, B., and Halley, R.B., 1985. Source rock evaluation of outcrop and borehole samples from Tongatapu and 'Eua Islands, Tonga, and from Viti Levu and Vanua Levu Islands, Fiji. In Scholl, D.W., and Vallier, T.L. (Eds.), Geology and Offshore Resources of Pacific Island Arcs-Tonga Region. Circum-Pac. Counc. Energy Miner. Resour., Earth Sci. Ser., 2:335-349.

Hawkins, J.W., 1974. Geology of the Lau Basin, a marginal sea behind the Tonga Arc. In Burk, C., and Drake, C. (Eds.), The Geology of Continental Margins: Berlin (Springer-Verlag), 505-520.

, 1989. Cruise Report-ROUNDABOUT Expedition, Legs 14, 15, R/V Thomas Washington. SIO Ref. Ser., 89-13.

Herzen, R.H., and Exon, N.F., 1985. Structure and basin analysis of the Southern Tonga Forearc. In Scholl, D.W., and Vallier, T.L. (Eds.), Geology and Offshore Resources of Pacific Island Arcs-Tonga Region. CircumPac. Counc. Energy Miner. Resour., Earth Sci. Ser., 2:55-74.

Karig, D.E., 1970. Ridges and basins of the Tonga-Kermadec island arc system. J. Geophys. Res., 75:239-254.

Lawver, L.A., Hawkins, J.W., and Sclater, J.G., 1976. Magnetic anomalies and crustal dilation in the Lau basin. Earth Planet. Sci. Lett., 33:27-35.

Mann, D.M., 1985. Multichannel profiles collected in 1982 in the Tonga region of the South Pacific. In Scholl, D.W., and Vallier, T.L. (Eds.), Geology and Offshore Resources of Pacific Island Arcs-Tonga Region. Circum-Pac. Counc. Energy Miner. Resour., Earth Sci. Ser., 2:49-54.

Parson, L., Hawkins, J., Allan, J., et al., 1992. Proc. ODP, Init. Repts., 135: College Station, TX (Ocean Drilling Program).

Parson, L.M., et al., 1989. Charles Darwin Cruise 33/88, 5 May-1 June 1988. Geophysical surveying and geological sampling in the Lau back-arc basin, SW Pacific Ocean. Inst. Oceanogr. Sci. Deacon Lab. Cruise Rep., 206.

Parson, L.M., Pearce, J.A., Murton, B.J., Hodkinson, R.A., Bloomer, S., Ernewein, M., Huggett, Q.J., Miller, S., Johnson, L., Rodda, P., and Helu, S., 1990. Role of ridge jumps and ridge propagation in the tectonic evolution of the Lau back-arc basin, southwest Pacific. Geology, 18:470-473.

Sandstrom, M.W., 1985. Organic chemistry of dredge samples and oil seeps from the southern Tonga platform. In Scholl, D.W., and Vallier, T.L. (Eds.), Geology and Offshore Resources of Pacific Island Arcs-Tonga Region. Circum-Pac. Counc. Energy Miner. Resour., Earth Sci. Ser., 2:129-129.

Abbreviations for names of organizations and publication titles in ODP reference lists
follow the style given in Chemical Abstracts Service Source Index (published by follow the style given in Chem
American Chemical Society).

\section{Ms 135SR-162}

Date of initial receipt: 2 July 1992

Date of acceptance: 10 May 1993 

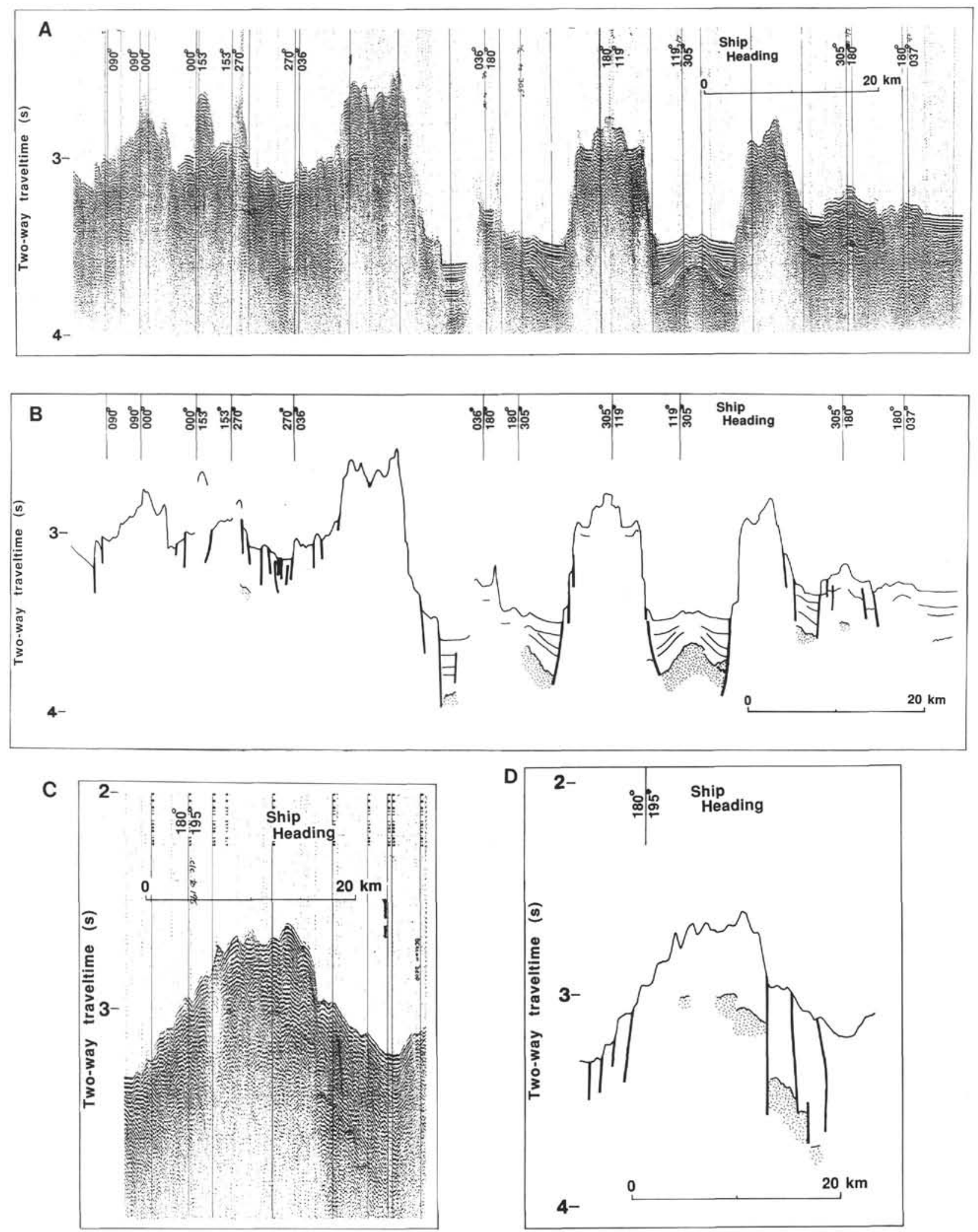

Figure 6. A. Seismic-reflection profiles acquired during Site 838 transit survey and approach. B. Line-drawn interpretation of Figure 6A. Stipple marks = "acoustic basement." Steep bold lines are faults. C. Seismic-reflection profiles acquired during Site 836 approach lines. D. Line-drawn interpretation of Figure 6D. 


\section{A}

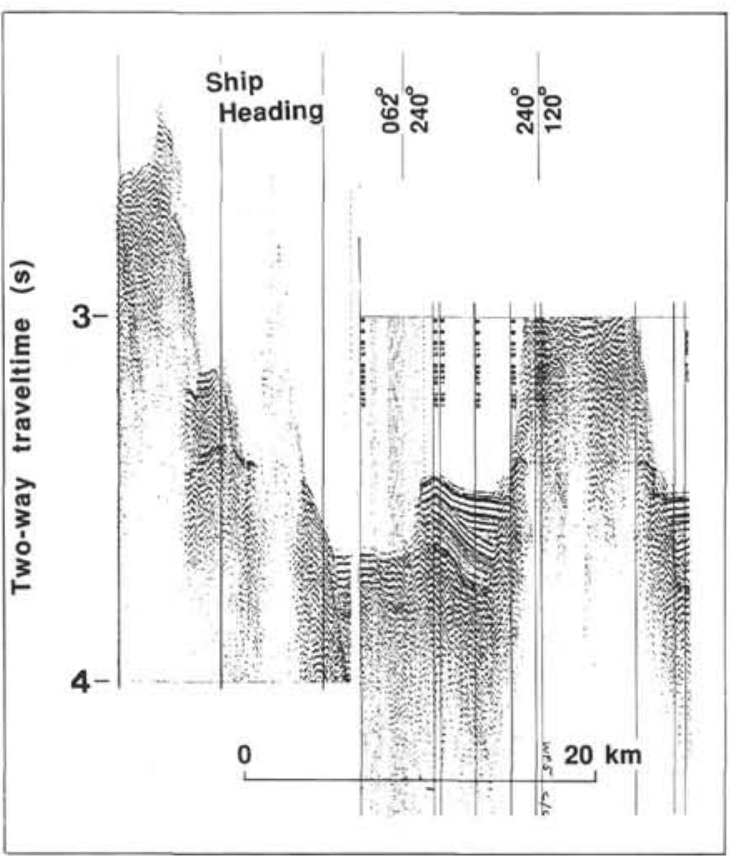

B

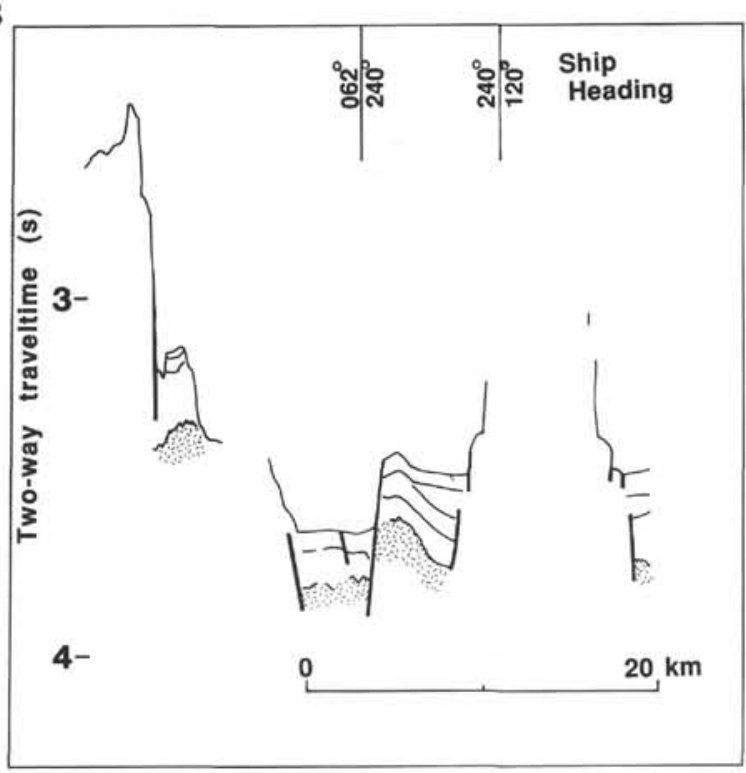

Figure 7. A. Seismic-reflection profiles acquired during Site 839 survey and approach. B. Line-drawn interpretation of Figure 7A. Stipple marks = "acoustic basement." Steep bold lines are faults. 

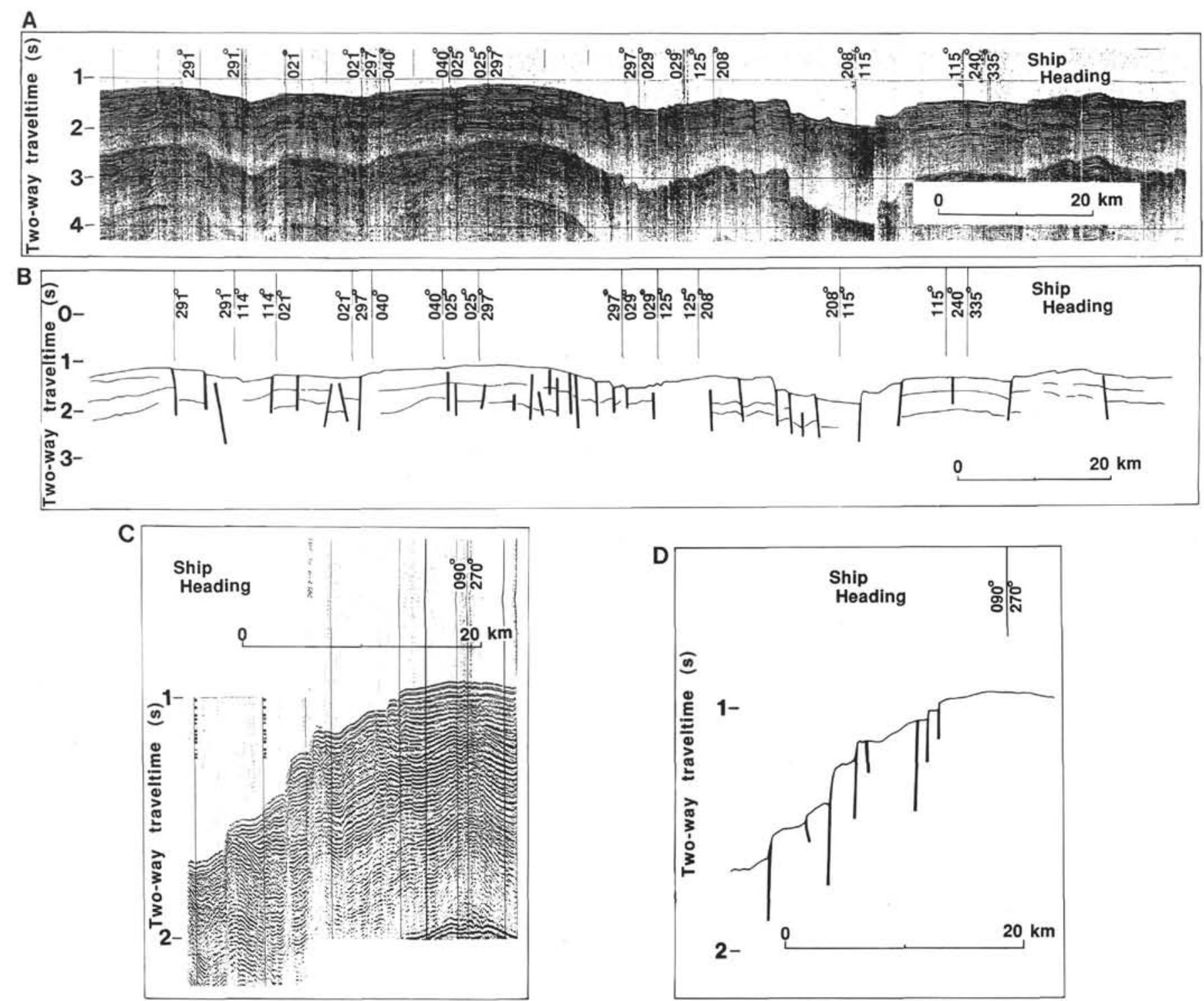

Figure 8. A. Seismic-reflection profiles acquired during Site 840 survey and approach. B. Line-drawn interpretation of Figure 8 A. Steep bold lines are faults. C. Seismic-reflection profiles acquired during Site 836 approach lines. D. Line-drawn interpretation of Figure 8C. 

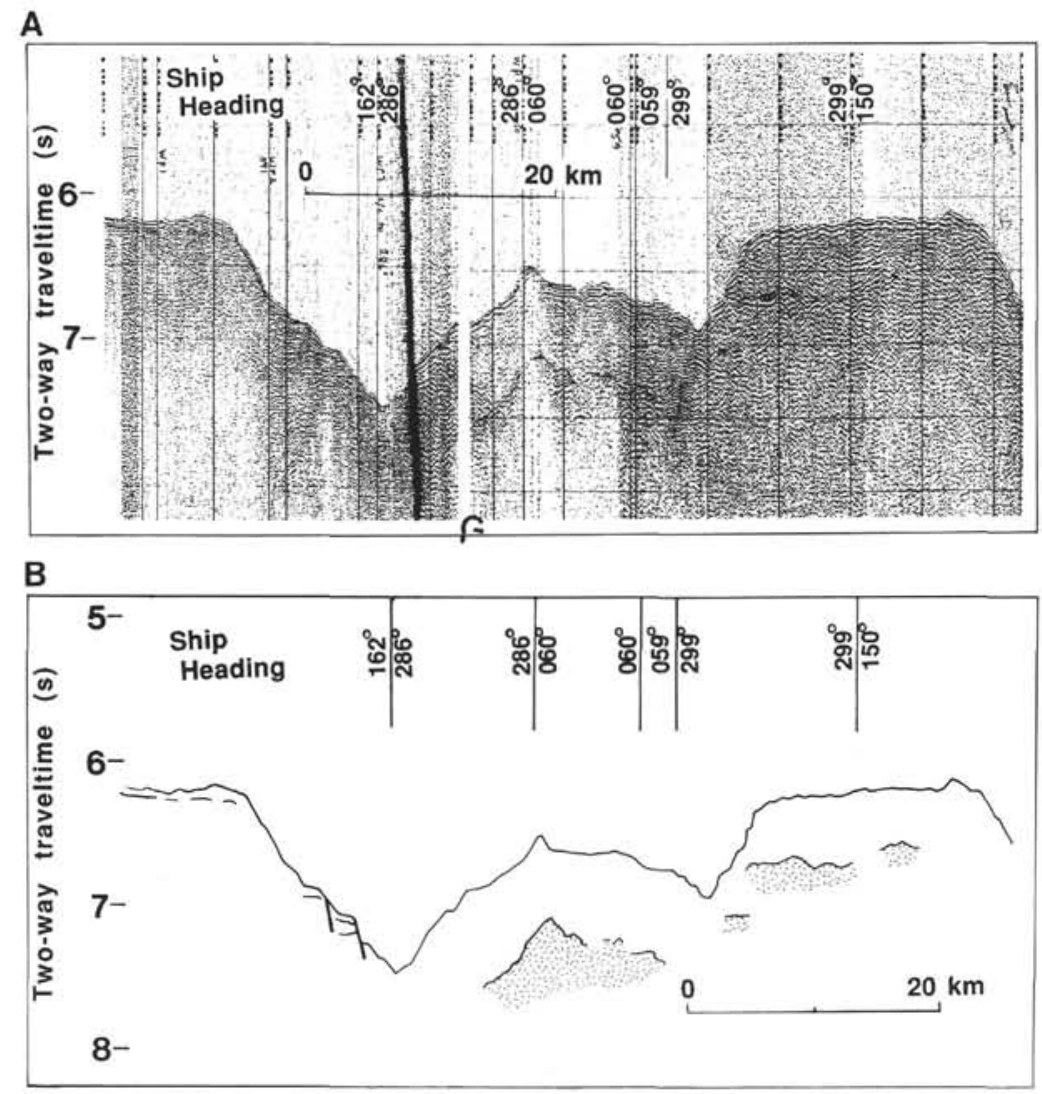

Figure 9. A. Seismic-reflection profiles acquired during Site 841 survey and approach. B. Linedrawn interpretation of Figure 9A. Stipple marks = "acoustic basement." 